\title{
Global Solar Energy Use and Social Viability in Malaysia
}

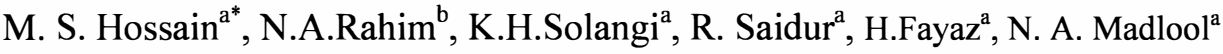 \\ ${ }^{a}$ Department of Mechanical Engineering \\ ${ }^{\mathrm{b}}$ Centre of Research UMPEDAC, Level 4, Engineering Tower \\ Faculty of Engineering, University of Malaya, 50603 Kuala Lumpur, Malaysia \\ Email: shouquat64@gmail.com
}

\begin{abstract}
Along with the enhancement of technology and alarming of global warming, various types of technologies are advanced worldwide nowadays to harness the energy from the sun such as solar thermal energy, ocean thermal energy conversion, solar ponds, solar tower and photovoltaic systems to utilize the energy in the majority of domestic applications and industrial sector to a certain extent. Subsequently, gradual increase usage of solar energy requires creating awareness among public to protect the environment in term of green campaign which is one of the hot topics among the Malaysians where there are many organizations organizing green campaign such as Environmental Protection Society Malaysia (EPSM), Malaysia Environment NGOs (MENGO) and Treat Every Environment Special Sdn. Bhd. (TRESS). Therefore, this study examines solar energy production and consumption worldwide by looking at various existing solar technologies to have the understanding of each technology. This article also intends to catch up specifically the social viability of solar energy production and use, with the availability of the resources for the full scale development.
\end{abstract}

Keywords: solar; Malaysia; social viability, energy

\section{INTRODUCTION}

Energy has become a fundamental part of people's daily lives as well as being vital to the social and economic progress of every country. In worldwide, energy in term of electricity, such as electricity and heat generated from solar, wind, ocean, hydropower, biomass, geothermal resources, bio fuels and hydrogen derived from renewable resources [1 and 2], is a necessity in our daily life as it provides power for lighting, electrical appliances, space conditioning, and water heating. Particularly in Malaysia, the residential energy use accounts for more than $14,365 \mathrm{GWh}$ or $19 \%$ of total electricity consumed in Peninsular Malaysia in year 2006 [1].

Solar energy is abundance, free and clean which does not make any noise or any kind of pollution to the environment. So far, many attempts have been made to extract solar energy by means of solar collectors, sun trackers and giant mirrors in order to utilize it for industrial purposes. In the view of world solar energy production and consumption, the PV cell productions from solar energy in the world have increased from $10 \mathrm{MWp} / \mathrm{yr}$ in 1980 to $1200 \mathrm{MWp} / \mathrm{yr}$ in 2004 . The trend of PV module production between 1988 and 2003, as shown in Figure 1, showing that PV panels have experienced $86 \%$ reduction in the cost while increasing in PV module production rate from the result of the price for solar energy was around $\$ 25 / \mathrm{W}$ in 1970 which has dropped to around $\$ 3.50 / \mathrm{W}$ in recent years [3 and 4]. Nowadays, PV integrated buildings use photovoltaic cells replacing traditional building materials in the wall, rooftop, and balcony or even as semitransparent glass windows even though high capital investment and low efficiency have limited the applications of PV systems in building industries [1].

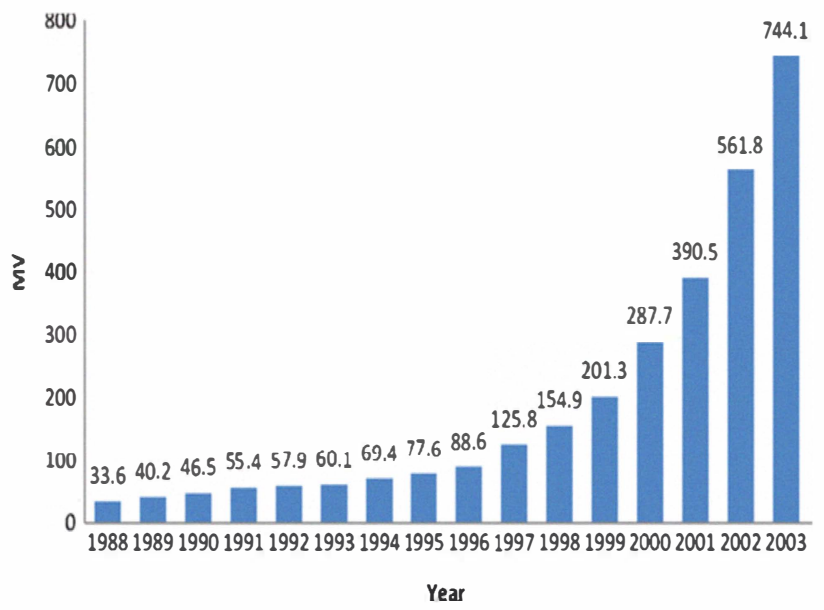

Fig.1. World PV Cell/Module Production in MWp [5]

It is also observed that the solar powered systems are reliable and cost-effective as they are largely applied in industrial processes in line with energy sustainability issues globally. Primary energy consumption released by Shell shows remarkable growth in PV solar electricity by 2030. Figure 2 shows the sustained growth of global energy consumption [6]. 


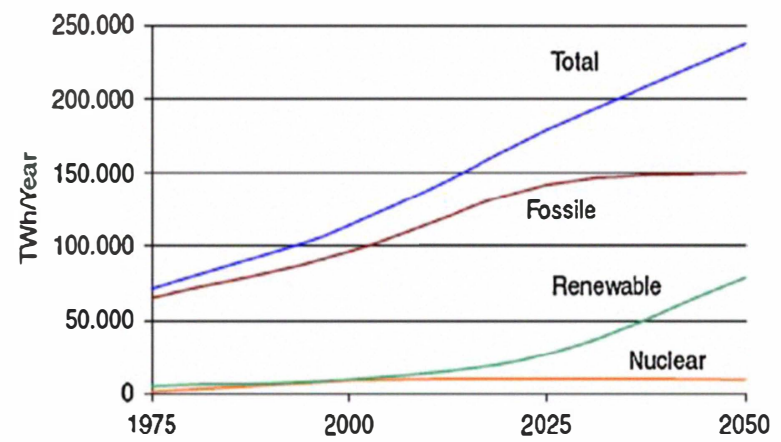

Figure 2: Global Energy Consumption [4]

Moreover, solar electricity is used in many remote and isolated industrial applications worldwide such as traffic lights, telecommunication instruments and geographicalposition systems (GPS) for the last 15 years. Most of remote installations are off grid or hybrid systems where off grid systems are independent of public grid and provide electricity to the load solely generated from solar irradiation [1and 4].

Due to rapid growth in conventional fuel prices and environmental constraints, enterprises are not attracted to use fossil fuels in industrial sector anymore. Therefore, applying renewable energy based systems in industries becomes sustained and popular worldwide as the greenhouse emissions also can be reduced significantly. Subsequently, traditional energy supplies become shifted to renewable sources of energy as new technologies are to be developed and applied in industries [1and 4].

\section{SOLAR ENERGY USE - PRODUCTION AND CONSUMPTION}

\section{A. Technology Use - Sources of Solar Thermo Production}

The advancement of technology allows solar energy production in various ways. In Table 1 shows the possibility of solar thermal usage for MSF (Multi Stage Flash) and MEE (Multiple Effect Evaporation) processes where solar PV systems can generate electricity for MVC and RO. In addition, they can be integrated to the hybrid RO and MSF systems [ 1 and 7]. Furthermore, worldwide market share for different water desalination technologies in 2000 shows that MSF and $\mathrm{RO}$ are the most common technologies used to desalinate sea and other sources of water as shown in Figure 3 [4].
TABLE 1: SOLAR ENERGY POTENTIAL FOR DESALINATION TECHNOLOGY [7]

\begin{tabular}{|l|l|l|l|l|}
\hline Solar energy & $\begin{array}{l}\text { Multi } \\
\text { Stage } \\
\text { Flash }\end{array}$ & $\begin{array}{l}\text { Multiple } \\
\text { Effect } \\
\text { Evaporation }\end{array}$ & $\begin{array}{l}\text { Mechanical } \\
\text { Vapor } \\
\text { Compression }\end{array}$ & $\begin{array}{l}\text { Reverse } \\
\text { Osmosis }\end{array}$ \\
\hline Photovoltaic & & & $\sqrt{ }$ & $\sqrt{ }$ \\
\hline $\begin{array}{l}\text { Solar } \\
\text { thermal }\end{array}$ & $\sqrt{ }$ & $\sqrt{ }$ & & \\
\hline $\begin{array}{l}\text { Solar } \\
\text { thermal } \\
\text { (electric) }\end{array}$ & $\sqrt{ }$ & $\sqrt{ }$ & $\sqrt{ }$ & $\sqrt{ }$ \\
\hline
\end{tabular}

(Source: Fiorenza et al., 2003) (a) all applications

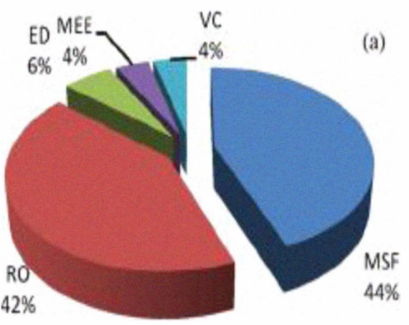

(b) seawater only

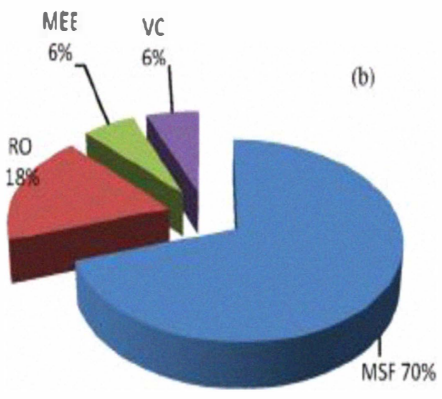

Fig.3. Desalination Technologies Market Share in 2000

[1 and 4]

\section{B. Solar Thermal Energy Conversion}

It can be stated that solar thermal is the conversion of solar irradiation into heat. Among renewable energy systems, solar thermal is considered as the most economical alternative. Typically, the systems use solar collectors and concentrators to gather solar radiation, store it and use for heating air or water in domestic, commercial or industrial plants.

The system allows obtaining temperature higher than $250 \circ \mathrm{C}$ with high efficiency; two axes tracking collectors are applied in power generation, stationary (non-tracking) and one axis PTCs are mainly used in industrial heat processes. Among the collectors, movable collectors require higher maintenance cost compared to other collectors. Table 2 illustrates the three main categories and types of solar collectors currently used where a concentration ration is also defined as the aperture area 
divided by the receiver/absorber area of the collector of each type is presented [8].

In this case, it is important to note that cost of the energy generated by solar thermal systems varies from 0.015 to 0.028 $\mathrm{C} £ / \mathrm{kWh}$ depending on initial investment and the type of solar collectors used. In other words, large scale solar thermal systems with large collector fields are more economical because they need less initial investment compared to several small plants; however, the collector cost is higher [8].

TABLE 2: TYPES OF SOLAR ENERGY COLLECTORS [8]

\begin{tabular}{|l|l|c|c|c|}
\hline \multicolumn{1}{|c|}{ Motion } & \multicolumn{1}{|c|}{ Collector Type } & $\begin{array}{c}\text { Absorber } \\
\text { Type }\end{array}$ & $\begin{array}{c}\text { Concentrat } \\
\text { ion Ratio }\end{array}$ & $\begin{array}{c}\text { Indicative } \\
\text { Temperature Range } \\
\text { (०C) }\end{array}$ \\
\hline Stationary & Flat plate collector (FPC) & Flat & 1 & $30-80$ \\
& Evacuated tube collector (ETC) & Flat & 1 & $50-200$ \\
\hline $\begin{array}{l}\text { Single- } \\
\text { axis } \\
\text { tracking }\end{array}$ & Presnel lens collector (FLC) & Tubular & $1-5$ & $60-240$ \\
& Cylindrical trough collector (CTC) & Tubular & $5-15$ & $60-300$ \\
\hline $\begin{array}{l}\text { Two-axes } \\
\text { tracking }\end{array}$ & Parabolic dish reflector (PDR) & Point & $100-1000$ & $60-300$ \\
\hline
\end{tabular}

\section{SOCIAL VIABILITY OF SOLAR ENERGY IN MALAYSIA}

\section{A. Solar Energy Status}

Solar energy innovations are likely to concern public and business policy makers in the decade ahead as the common problem what the world is facing nowadays is the energy problem. Sooner or later, the focus of concern is moving from the general to the specific, from the macro to the microenvironment, from the national level to the regional and state levels. Therefore, particularly in Malaysia, this is alarming that everyone needs to create awareness about solar energy as the government is also planning to do a lot of awareness regarding the renewable energy for the regard of benefits for people, for instance, in the 10th Malaysia Plan (2011-2015) it has also set a target of 5.5\% RE in the country's energy mix [9 and 10].
In term of creating public awareness on benefits of solar energy use and the environmental effects, nowadays it can be seen that green campaign is one of the hot topics among the Malaysians. There are many organizations organizing green campaign such as Environmental Protection Society Malaysia (EPSM), Malaysia Environment NGOs (MENGO) and Treat Every Environment Special Sdn. Bhd. (TRESS). As an example of the benefits of solar energy technology instalment, price of solar energy, which is the most concern factors on this regard, is very reasonable and vary depending upon the amount of energy needed and the size of the panels required, for instance, solar energy systems cost between $£ 2,400$ and $£ 5,000$ installed for domestic hot water [11]. Furthermore, DIY hot water heating kits are available which cost about $£ 1,500$ to compare with photovoltaic systems which are more expensive costing from $£ 5,000$ to around $£ 9,000$ installed. In term of solar energy production and consumption status in Malaysia, it can be seen that solar power in Malaysia or also known as photovoltaic (PV) system is estimated to be four times the world fossil fuel resources . For instance, the 5-year Malaysian Building Integrated Photovoltaic Technology 
Application Project (MBIPV), jointly funded by the Government of Malaysia, the Global Environment Facility (GEF) and the private sector, has been launched in 2005 where the project has several demonstrations of PV projects in various sectors including residential houses and commercial building [10 and11].

\section{B. Daily Electricity Use - Surveyed Data in Malaysia}

Social viability of solar energy use can be counted in form of daily electricity use in Malaysia as the household electricity consumption is very much dependent on the family size, living habits, age and number of electrical appliances and usage time. According to the study, the average electricity consumption can be seen into three different categories of household; the low cost house with average spending of approximately MYR65 per month, medium cost house spending about MYR110 per month and for bungalow spending up to MYR350 per month. The cost of energy used by various appliances in Malaysia is shown in Figure 4.

Furthermore, it also can be seen that water heating is the second largest cost day after air conditioning according to Table 3 indicating the survey data for the average monthly electricity consumption and water usage for a typical household in Kuala Lumpur where the usage of water heater is $14 \%$ of total energy consumption per month in a typical urban house. And then, Table 4 shows the average electricity needed to heat up the water to the design hot water temperature [1 and 8].

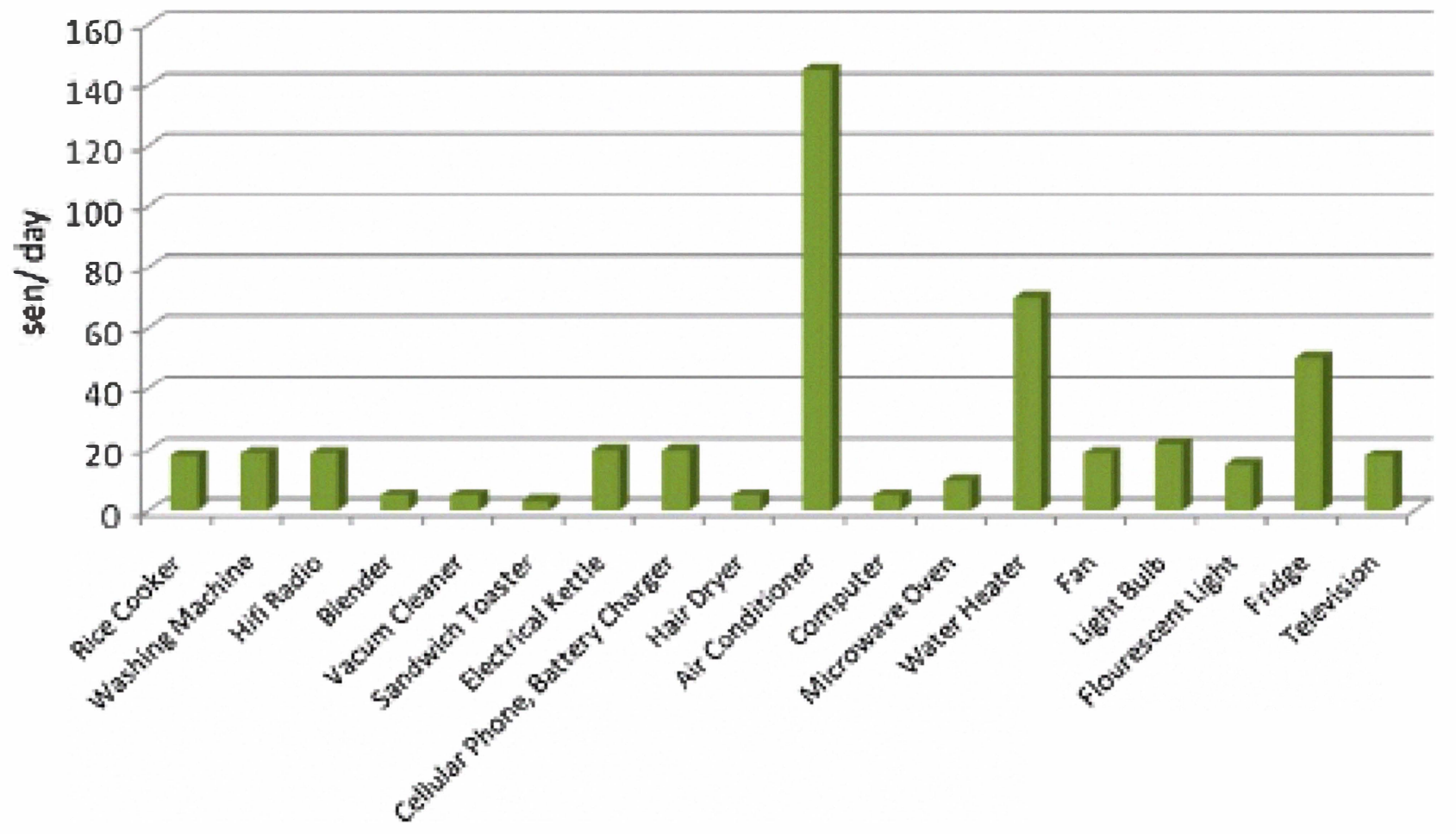

Figure 4: Estimated Daily Electricity Cost of Various Domestic Appliances [1 and 10]. 
TABLE 3: AVERAGE MONTHLY ELECTRICITY CONSUMPTION FOR A TYPICAL HOUSEHOLD

\begin{tabular}{|c|c|c|c|c|c|c|c|c|c|c|c|c|}
\hline Typical household & \multicolumn{10}{|c|}{ Month } \\
\hline & Jan & Feb & Mar & Apr & May & Jun & Jul & Aug & Sep & Oct & Nov & Dec \\
\hline $\begin{array}{c}\text { Monthly energy used } \\
\text { (kWh/mth) }\end{array}$ & 380 & 359 & 376 & 388 & 379 & 344 & 357 & 356 & 374 & 359 & 360 & 355 \\
\hline $\begin{array}{c}\text { Water heater 14\% } \\
\text { (kWh/mth) }\end{array}$ & 54 & 51 & 53 & 545 & 49 & 49 & 50 & 50 & 53 & 51 & 51 & 50 \\
\hline $\begin{array}{c}\text { Air conditioner 21\% } \\
\text { (kWh/mth) }\end{array}$ & 80 & 76 & 79 & 82 & 73 & 73 & 75 & 75 & 79 & 76 & 76 & 75 \\
\hline $\begin{array}{c}\text { Light and appliances } \\
\text { (kWh/mth) }\end{array}$ & 247 & 234 & 245 & 253 & 247 & 224 & 23 & 232 & 244 & 234 & 234 & 231 \\
\hline
\end{tabular}

TABLE4: MONTHLY ELECTRIC POWER NEEDED [5 and 8]

\begin{tabular}{|l|c|}
\hline \multicolumn{1}{|c|}{ Month } & Electrically power (KWh) \\
\hline January & 4.977 \\
February & 4.857 \\
March & 4.822 \\
April & 4.842 \\
May & 4.857 \\
June & 4.932 \\
July & 4.977 \\
August & 4.951 \\
September & 4.902 \\
October & 4.867 \\
November & 4.904 \\
December & 5.004 \\
\hline
\end{tabular}

According to the above-mentioned surveyed data, it can be seen clearly that consumption of energy, particularly electricity, is relatively high with the time line of the season. In other words, it is showing that use of solar energy technology is better to increase along with creating more awareness of the long term sustainable benefits of this technology to the society and environment as well as by emphasizing more on incentives of new business entry for this particular energy sector.

\section{CONCLUSIONS}

It is evident to say that solar energy systems can be considered either as the power supply or applied directly to a process. Furthermore, large scale solar thermal systems with large collector fields are economically viable due to the usage of stationary collectors as solar PV systems are reliable substitutes to be considered as an innovative power source in building, processes industries and water desalination systems. Besides that, the economic outlook for these systems is more viable when the system is operating in remote regions where there is no access to a public grid. In addition, other technical and economical variables such as wear and tear, initial and running costs, economic incentives, PV module diminishing price rate and oil price raises should not be neglected. In term of world solar energy use, the various existing solar technologies can be seen in order to enhance the understanding of each technology and its associated challenges; the price for installation. Moreover, these outlooks provide a suitable basis to recognize advantages and drawbacks in its current usage of energy and further implementation in Malaysia on this regard specifically with the availability of the resources for the full scale development as there is a great potential for Malaysia to move from fossilbased generation towards the RE. 


\section{REFERENCES}

[1] Mahlia, T.M.I. and P.L. Chan, Life cycle cost analysis of fuel cell based cogeneration system for residential application in Malaysia. Renewable and Sustainable Energy Reviews, 2011. 15(1): p. 416-426.

[2] Ab Kadir, M.Z.A., Y. Rafeeu, and N.M. Adam, Prospective scenarios for the full solar energy development in Malaysia. Renewable and Sustainable Energy Reviews, 2010. 14(9): p. 3023-3031.

[3] Bradford, T., Solar revolution: the economic transformation of the global energy industry. Massachusetts: The MIT Press, 2006.

[4] Hoffmann, W., PV solar electricity industry: Market growth and perspective. Solar Energy Materials and Solar Cells, 2006. 90(18-19): p. 3285-3311.

[5] Nathan, S.L., Basic research needs for solar energy utilization. Report of the basic energy sciences workshop on solar energy utilization. California Institute of Technology, 2005. 18(21): p. 276.

[6] Wittmann, M., Breitkreuz, H., Schroedter-Homscheidt, M. \& Eck, M., Case studies on the use of solar irradiance forecast for optimized operation strategies of solar thermal power plants. IEEE Journal of Selected Topics in Applied Earth Observations and Remote Sensing 2008. 1(1): p. 18-2.

[7] Fiorenza, G., V.K. Sharma, and G. Braccio, Techno-economic evaluation of a solar powered water desalination plant. Energy Conversion and Management, 2003. 44(14): p. 2217-2240.

[8] Kalogirou, S., The potential of solar industrial process heat applications. Applied Energy, 2003. 76(4): p. 337-361.

[9] Saidur, R., Islam, M. R., Rahim, N. A. \& Solangi, K. H., A review on global wind energy policy. Renewable and Sustainable Energy Reviews, 2010. 14(7): p. 1744-1762.

[10] Zhang, Z., Asian energy and environmental policy: Promoting growth while preserving the environment. Energy Policy, 2008. 36(10): p. 3905-3924.

[11] Islam, M. R., Saidur, R., Rahim, N. A. \& Solangi, K. H., Usage of solar energy and its status in Malaysia. (ISSN 1823-6379). Online at http://ejum.fsktm.um.edu.myEngineering e-Transaction, 2010. 5(1): $\mathrm{p}$. $6-10$ 